His outstanding work was recognized by his election in 1929 to the fellowship of the Royal Society, on the Council of which he afterwards served; he was an honorary Fellow of the Royal College of Physicians. He also served as a member of the Medical Research Council. The University of Leeds conferred the degree of LL.D. upon him in 1943.

In 1946 Raper became full-time dean of the Medical School at Manchester, and by his wisdom and tact was responsible for the smooth operation of the changes in the pattern of medical education which resulted from the passing of the National Health Act. His wide experience was of great value also in the deliberations of the General Medical Council, in the educational work of which he took an important part.

Raper's death took place a few weeks before he was due to retire, and it was characteristic of the man that he should have continued unobtrusively and effectively at work right up to the end. In his personal character he was remarkable for modesty and for his kindly interest in everyone who came in contact with him, young and old alike. As the head of a department it was his policy to encourage by all the means in his power the independent research projects of his younger colleagues ; in this way he succeeded in maintaining a variety of interests and of outlook in the teaching for which he was respons. ible. He was a redoubtable opponent on matters of principle, and his case was always based on complete intellectual honesty; but he was prepared to listen patiently to another's point of view, nor were disagreements ever allowed to affect his universally friendly relations with his colleagues.

Apart from his work, Raper's interests lay in water-colour painting. Though somewhat defective in colour vision, he had a keen appreciation of form and by his enthusiasm encouraged members of his staff to cultivate such talents as they had for sketching. In his younger days he was a keen cricketer, but latterly had given much attention to the magnificent garden of his house at Prestbury.

In Raper's death physiology has sustained an irreparable loss. His pupils, many of whom now occupy important posts, will always remember his teaching and will strive to be worthy of his incomparable example.

W. Schlapp

\section{Miss E. C. Higgins}

Ellan Charlotte Higgins, principal of the Royal Holloway College during 1907-35, died in Edinburgh on December 13. Born in London in 1871 of Scottish parents-her maternal grandfather being David Ramsay Hay (see "Dictionary of National Biography")- - she was educated at Edinburgh Ladies' College and at the Royal Holloway College, London. She achieved the unique distinction of being placed in the first classes, in the same year (1894), in final honours mathematics at Oxford (an examination then open to Royal Holloway students) and in B.A. (Honours) English, with the Gilchrist Prize, in London. She was on the staff of Cheltenham Ladies' College during 1895-1907, latterly as head mathematics lecturer, and had been a governor of that College since 1924. She was chairman of the house committee of St. Gabriel's Church of England Training College for Women during 1932-44. From 1911 until 1935 she was a member of the Senate of the University of London, taking an ever-increasing share in its business; towards the end of this time she was on four of its five standing committees, as well as the finance and general purposes committee. In particular, she did notable work as chairman of the Matriculation Board (later the Matriculation and School Examinations Council).

The Royal Holloway College advanced in status and reputation during her many years as principal. Its distinguished first holders of professorships in the University of London were appointed; until 1922 these were all in science-Margaret J. Benson (already a college lecturer), botany, appointed 1912 ; G. Barger, chemistry, 1913, followed by T. S. Moore, 1914 ; F. Horton, physics, 1914; A. E. Jolliffe, mathematics, 1920. The chemistry building was extended, and in 1926 a building providing good new laboratory accommodation in physics and botany was opened. Students, as well as junior members of the staff, who came under Miss Higgins, later obtained many of the highest academic and scholastic posts open to women or attained distinction in a variety of other careers. The student body became, as it still is, a well-united society capable of concerted effort when required. Miss Higgins maintained dignity and spaciousness in the domestic life of the College and in its public occasions. The benefit of her care for its furnishings is still felt in the present more austere times.

Miss Higgins belonged perhaps more to the pioneering days of university education for women than to the time when their full participation in all academic pursuits is taken for granted. Thus, although the research work of individual colleagues flourished in her time, she scarcely contemplated her College becoming a centre of research as it has done in recent years (when men, as well as women, have been admitted as postgraduate workers). Yet the ease with which this development has occurred is a tribute to the level to which she had done so much to raise the College.

Except in private life, Miss Higgins was brusque in manner. Behind this façade, she was warm-hearted and constantly performed acts of kindness which she herself revealed to none but their recipients. Her independence and practicalness, combined with her concern for the ceremonies of life, found expression in her quite famous clothes-her invariable and rather mannish day-attire and her magnificent but fashiondefying evening-dresses. Until her last brief illness, her vitality remained almost unimpaired: she was an enthusiastic and experienced alpinist, and made her last ascent to the Matterhorn hut at the age of seventy-six.

W. H. MaCreA

\section{Dr. Ivar Tragardh}

The death occurred at Stockholm, on May 22, 1951, of Dr. Ivar Tragardh. Ivar Tragardh was born on September 16, 1878, at Jarfalla, near Stockholm, and studied at Uppsala. In 1901 he became a member of the Jagerskiold expedition to Egypt and the Sudan, and in 1904, with the help of the Vega Fund, he visited Natal and Zululand. He obtained his Ph.D. degree in 1905.

In 1910 Tragardh was appointed assistant in the Department of Entomology, Centralanstalten fur Jordbruksforsok, Stockholm. From 1915 until 1944 he was professor and chief of the Department of Entomology, Forestry Research Institute, at Experimentalfaltet, Sweden. 